\title{
'Plus est in RE QUAM IN EXISTIMATIONE'. LA TERMINACIÓN ANTICIPADA DEL CONTRATO DE CONCESIÓN MUNICIPAL POR DECLARACIÓN ADMINISTRATIVA UNILATERAL. ASPECTOS DE DERECHO PRIVADO Y DE DERECHO PÚBLICO
}

['Plus est in re quam in existimatione'. Early Termination of Administrative Contract of Concession caused by an Administrative self Decision. Aspects from both Public and Private Law]

\author{
Patricio-Ignacio CARVAJAL ${ }^{*}$ \\ Pontificia Universidad Católica de Chile
}

\begin{abstract}
RESUMEN
Desde el punto de vista del derecho público, para la terminación anticipada y unilateral de una concesión municipal no basta con sólo indicar o invocar la causal legal que se estime pertinente, ni la norma legal o contractual de la cual emane la obligación hipotéticamente incumplida. Se debe señalar la gravedad. Pues, de otra forma, el órgano administrativo atendería sólo formalmente al deber de propender al bien común, atropellándose sustancialmente los derechos y garantías

AbSTRACT

From the ponit of view of Public Law, for an anticipated termination of a contract regarding an Administrative (municipal) concession, caused by unilateral decision of the Administration it self, it is not enough just mention the legal provision related to, or the regarding legal or contractual clause to considered an hipotetic breach of contract. It shall be argued its gravity. In a different way, Public Administration just formally fulfils its duty to reach the
\end{abstract}

Recibido el 30 de mayo y ACEPTADo el 15 de junio de 2016

* Patricio I. Carvajal, Profesor de la Facultad de Derecho de la Pontificia Universidad Católica de Chile. Mail: carvajal@uc.cl. Este trabajo corresponde a las investigaciones producidas en virtud del Proyecto Anillo-CONICYT, código SOC 1111 y también por el proyecto FONDECYT Regular No 1130175. 
del concesionario, lo cual pugna con los artículos 1 inciso cuarto, 7 y 19 No 21 y No 24 de la Constitución Política. Desde el punto de vista del derecho privado, la resolución del contrato tiene lugar respecto de obligaciones cuyo incumplimiento rompe el "equilibrio" o "equidad" contractual; al incidir de manera importante en los "fines prácticos" queridos por las partes. Por contraste, la resolución del contrato no puede tener lugar respecto de incumplimientos de poca relevancia, referidos a "minucias", como es el caso de obligaciones "secundarias" o "accesorias". La terminación unilateral anticipada no puede ser un mecanismo "para deshacerse de contratos molestos o meramente inconvenientes". En suma, para una terminación unilateral anticipada de una concesión municipal, "plus est in re quam in existimatione".

\section{Palabras Clave}

Concesión Municipal - Terminación anticipada del contrato - gravedad del incumplimiento del contrato - Derecho Público - Derecho Privado. benefit of the general public, and injures the rights of the licensee, against articles 1, 7 and 19 No 21 and No 24 of the Political Constitution. From the point of view of Private Law, the termination of contract proceeds about breaches that break down the "balance" or "equity" of contract; namely, geting lost the "practical pourpuses" desidered by both parties. That is why irrelevant breaches of contract couldn't be considered for an anticipated termination of contract. It means that subtilitates as "secondaries" or "accessories" obligations are not enaough to. Unilateral anticipated termination of contract could not be a way "to cut of unpleasant or merely unconvinient contracts". Briefly, for an unilateral anticipated termination of an Administrative concession, it must be taken into account that "plus est in re quam in existimatione".

\section{KEYWORDS}

Administrative (Municipal) concession - anticipated termination of contract - gravity of breach of contract - Public Law - Private Law.

Las antiguas dicciones "plus est in re quam in existimatione" y "plus est in veritate quam in opinione" son eficaces formulaciones hermenéuticas, cuyo origen de cuño romano ya hemos revisado en otro lugar ${ }^{1}$, las cuales están integradas al sistema general de interpretación actual, incluida también la administrativa ${ }^{2}$. Esto, por cuanto tales dicciones ${ }^{3}$ sintetizan dos posiciones que el intérprete debe necesariamente asumir. Para el caso que se propone

${ }^{1}$ Carvajal, Patricio-Ignacio, La compraventa a un impúber sin autorización del tutor. Un estado de la cuestión en torno a D. 41,4,2,15, en REHJ. 33 (2011) pp. 145171.

2 Por todos, GuZMán Brito, Alejandro, La interpretación administrativa en el derecho chileno (Thomson Reuters La Ley, Santiago, 2014) pp. 153 a 155.

${ }^{3}$ Para la pluralidad terminológica con las que este tipo de proposiciones (principios) se han designado en nuestra historia jurídica, GuZMÁn BRITO, Alejandro: El origen y la expansión de la idea de principio del derecho (Thomson Reuters La Ley, Santiago), 2014, pp. 277 a 344. 
tratar en el presente trabajo, la proposición hermenéutica viene dada por "plus est in re quam in existimatione". Vale decir, la administración podrá terminar unilateralmente un contrato siempre y cuando tal decisión-que no es sino una interpretación de lo pactado-, tenga un fundamento que vaya más allá de la mera estimación del propio órgano administrativo, y se funde por tanto en la "realidad" (res) de las cosas: esto es, en razones siempre "graves" para tal terminación anticipada, sin importar que se haya podido integrar al clausulado del contrato, por la propia Administración, otras circunstancias leves con el objeto de respaldar hipotéticamente una mera "estimación" (existimatio) futura de provocar tal terminación de la concesión municipal. Hacia esta constatación, relativa a que en esta materia "plus est in re quam in existimatione", se orienta el presente trabajo.

Las siguientes son las principales disposiciones relativas a la terminación anticipada de las concesiones administrativas municipales:

a) El artículo 36 inciso tercero de la Ley 18.695, Orgánica Constitucional de Municipalidades: "Las concesiones darán derecho al uso preferente del bien concedido en las condiciones que fije la municipalidad. Sin embargo, ésta podrá darles término en cualquier momento, cuando sobrevenga un menoscabo o detrimento grave al uso común o cuando concurran otras razones de interés público".

b) El artículo 37 inciso noveno del mismo cuerpo legal: "La concesión sólo se extinguirá por las siguientes causales: [...] 2.- Incumplimiento grave de las obligaciones impuestas al concesionario, y 3. - Mutuo acuerdo entre la municipalidad y el concesionario".

c) El artículo 13 de la Ley 19.886, de Bases sobre Contratos Administrativos de Suministro y Prestación de Servicios (al cual reenvía el artículo 66 de la Ley 18.965): "Los contratos administrativos regulados por esta ley podrán modificarse o terminarse anticipadamente por las siguientes causas:

[...] b) El incumplimiento grave de las obligaciones contraidas por el contratante [...] d) Por exigirlo el interés público o la seguridad nacional. e) Las demás que se establezcan en las respectivas bases de la licitación o en el contrato. Dichas bases podrán establecer mecanismos de compensación y de indemnización a los contratantes. Las resoluciones o decretos que dispongan tales medidas deberán ser fundadas".

Tal como se señala por la jurisprudencia, la terminación anticipada del contrato por declaración administrativa es una facultad de carácter completamente excepcional ${ }^{4} y$, por cierto, en ningún caso se considera ilimitada ${ }^{5}$.

${ }^{4}$ Finger Access S.A. con Ilustre Municipalidad de Antofagasta, Corte Suprema, casación en el fondo, 30.6.2008, Rol No 1370-2007 (Considerando Segundo), LegalPublishing Cita Online: CL/JUR/2785/2008.

5 Servicios de Estacionamientos Controlados S.A con I. Municipalidad de 
Se trata, pues, de una facultad conferida a la Administración en virtud de normas expresas del Derecho público (1.), si bien ciertos aspectos no tratados por éstas se regulan supletoriamente por el Derecho privado (2.).

Desde el punto de vista del Derecho público, el carácter excepcional de la declaración administrativa de terminación anticipada del contrato deriva, en primer lugar, de que las normas que facultan para ello a la Administración deben intervenir (e interpretarse) a manera de "excepción" y "por motivos fundados" (artículo 19 No 21 inciso segundo de la Constitución Política). En segundo lugar, también deben entenderse de manera excepcional, tanto en cuanto la declaración de terminación anticipada del contrato priva al particular de sus derechos emanados desde aquél como concesionario (artículo 19 No 24 de la Constitución Política). Y, asimismo, en tercer lugar, porque la Administración sólo puede hacer aquello a lo que la autorice expresamente la ley, y por tanto la interpretación de sus normas es restrictiva, según el principio de juridicidad (artículo 7 de la Constitución Política). Y, como se sabe, del punto de vista del Derecho privado, según las normas que rigen la contratación entre los particulares no le es permitido a ninguna de las partes extinguir el contrato unilateralmente (salvo en hipótesis como las del contrato de mandato, que no viene al caso), pues ello infringiría la ley del contrato (artículo $1.545 \mathrm{del}$ Código Civil).

Por lo tanto, resulta a todas luces evidente que las normas de Derecho público que admiten esta terminación anticipada de la concesión administrativa son del todo excepcionales.

Pero, además, todavía desde la perspectiva del Derecho privado, cuando la declaración administrativa de terminación anticipada del contrato se refiere a hipótesis tales como el incumplimiento grave de las obligaciones del concesionario, sus normas resultan también una excepción a la ley del contrato por razones adicionales. Las normas de la institución análoga de la resolución del contrato por incumplimiento, tienen pacíficamente la consideración de sancionatorias y, por tanto, excepcionales ${ }^{6}$. En conse-

Melipilla, Corte de Apelaciones de San Miguel, recurso de protección, 4.3.2011, Rol No 323-2010 (“Considerando, Decimotercero"), LegalPublishing Cita Online: CL/JUR/10647/2011.

${ }^{6}$ Rodríguez, Pablo, Extinción no convencional de las obligaciones (Editorial Jurídica de Chile, Santiago, 2008), p. 213; MejÍAs, Claudia, El incumplimiento resolutorio en el Código Civil (Abeledo Perrot, Santiago, 2011), p. 43; DE la Maza, Íñigo, Contratos especiales (Comentarios de jurisprudencia), en Revista Chilena de Derecho Privado 17(2011) p. 249; CoRral, Hernán, Contratos y daños por incumplimiento. Estudios sobre su régimen jurídico y la responsabilidad por incumplimiento (Abeledo Perrot-LegalPublishing, Santiago, 2010), p. 224. 
cuencia, como estas normas se aplican supletoriamente a la terminación administrativa anticipada por incumplimiento (aunque en el caso civil, jamás se admitiría esta terminación sin siquiera una declaración judicial) ${ }^{7}$, se puede añadir a las razones que hacen de la terminación anticipada de la concesión, en general, una institución excepcional, que si dicha terminación se funda en el incumplimiento contractual del concesionario, también tiene tal carácter según el Derecho privado, ahora por razones particulares a la causa de esta terminación.

La consecuencia de que, tanto por razones jurídicas públicas como privadas, la terminación anticipada sea una institución de carácter excepcional $^{8}$ y no ilimitada ${ }^{9}$, es que para su legítima procedencia se requiere satisfacer cabalmente ciertos requisitos.

\section{Requisitos de Derecho público}

En cuanto a los requisitos generales de la declaración de terminación anticipada del contrato, resulta indispensable que ésta se contenga: $a$ ) en un acto administrativo fundado, tanto en los hechos como en el Derecho; $\mathrm{y}$, asimismo, b) que el fundamento último que sirva de motivación sea, siempre y en todo caso, el bien común o interés público; al turno que, además, c) se debe invocar, también en términos explícitos, una causa legal. Sólo así se respetan las disposiciones al efecto y, especialmente, el principio de juridicidad que rige al ente administrativo.

a) Acto administrativo fundado en los hechos y en el Derecho. El acto administrativo que declare la terminación anticipada del contrato debe ser fundado, en razón de lo dispuesto por el artículo 13 de la Ley 19.886, de

7 Vid., con la bibliografía citada, Corral, Hernán, Contratos y daños por incumplimiento (cit. n. 5) p. 230. Esto resulta inadmisible en nuestro Derecho privado ex lege y, en la doctrina nacional, apenas un autor se ha atrevido tímidamente a proponer la discusión, sin éxito, sobre su admisibilidad teórica; apreciando que tal resolución extrajudicial, a diferencia de lo que ocurre en nuestro Ordenamiento, sí aparece contemplada por la ley en alguna experiencia del Derecho comparado. PizARRO, Carlos, ¿Puede el acreedor poner término unilateral al contrato?, en Revista Ius et Praxis 13 (2007)1 pp. 11-28. Vid., aceptando la necesidad de sentencia, aunque la critique, Elorriaga, Fabián, Las dificultades de los remedios por incumplimiento contractual en la experiencia chilena, en Mondaca, AleXis -Aedo, Cristí́n (editores), Nuevos Horizontes del Derecho Privado (Librotecnia, Santiago, 2013), pp. 406 a 410.

${ }^{8}$ Finger Access S.A. con Ilustre Municipalidad de Antofagasta, Corte Suprema, casación en el fondo, fecha 30.6.2008, Rol No 1370-2007 (Considerando Segundo), LegalPublishing Cita Online: CL/JUR/2785/2008.

9 Servicios de Estacionamientos Controlados S.A con I. Municipalidad de Melipilla, Sent. Corte Apelaciones de San Miguel, recurso de protección, fecha 4.3.2011, Rol No 323-2010 (Considerando Decimotercero), LegalPublishing Cita Online: CL/JUR/10647/2011. 
bases sobre contratos administrativos de suministro y prestación de servicios, que establece: "Los contratos administrativos regulados por esta ley podrán... terminarse anticipadamente... Las resoluciones o decretos que dispongan tales medidas deberán ser fundadas". Esta norma sin duda rige en el ámbito de las concesiones municipales en virtud del reenvío hecho por el artículo 66 incisos primero y segundo ${ }^{10}$ de la Ley 18.965, Orgánica constitucional de municipalidades. A su vez, para que se declare la terminación anticipada del contrato debe invocarse, de la Ley 18.695, su artículo 36 inciso tercero: “...ésta [sc. la municipalidad] podrá darles término [sc. a las concesiones] en cualquier momento, cuando sobrevenga un menoscabo o detrimento grave al uso común o cuando concurran otras razones de interés público"; $\mathrm{y}$, cuando sea del caso, su artículo 37 inciso noveno: "La concesión sólo se extinguirá por las siguientes causales... 2.- Incumplimiento grave de las obligaciones impuestas al concesionario". En consecuencia, la interpretación armónica de todas estas normas da clara cuenta de que el decreto alcaldicio que termine anticipadamente un contrato de concesión administrativa debe estar fundado.

En cualquier caso, además de estos argumentos provenientes de los textos especiales, hay razones palmarias que proceden del marco jurídico general que regula los actos administrativos, las cuales permiten reafirmar que la declaración administrativa de terminación anticipada del contrato debe estar motivada.

Cuando la manifestación de voluntad administrativa consiste en la terminación del contrato de concesión ${ }^{11}$, también debe respetarse la regu-

10 "La regulación de los procedimientos administrativos de contratación que realicen las municipalidades se ajustará a la Ley de Bases sobre Contratos Administrativos de Suministro y Prestación de Servicios y sus reglamentos. I Asimismo, el procedimiento administrativo de otorgamiento de concesiones para la prestación de servicios por las municipalidades se ajustará a las normas de la citada ley y sus reglamentos, salvo lo establecido en los incisos cuarto, quinto y sexto del articulo $8^{\circ}$ de la presente ley, disposiciones que serán aplicables en todo caso".

${ }_{11}$ Así, con especial referencia a las concesiones municipales y principalmente en cuanto al procedimiento de adjudicación y la celebración del contrato de concesión, en Carvajal, Patricio-Ignacio, Sobre la naturaleza de las concesiones administrativas y su carácter contractual (en prensa). Allí hemos visto que nuestra legislación ordena que la adjudicación sea emitida a través de un acto administrativo fundado: Ley 19.886, de bases sobre contratos administrativos de suministro y prestación de servicios, 10 inciso primero: "El contrato se adjudicará mediante resolución fundada de la autoridad competente, comunicada al proponente". Decreto No 250, del Ministerio de Hacienda, del año 2004, que aprueba Reglamento de la Ley No19.886 de bases sobre contratos administrativos de suministro y prestación de servicios, artículo 2 No 1: "Adjudicación: Acto administrativo fundado, por medio del cual la autoridad competente selecciona a uno o más Oferentes para la suscripción de un Contrato de Suministro o Servicios, regido 
lación del procedimiento administrativo. Esto, por cuanto la declaración administrativa de terminación anticipada del contrato también es un acto de la Administración producido en virtud de un procedimiento lega ${ }^{12}$ que cabe del todo en la definición del procedimiento administrativo (artículos 3 inciso segundo ${ }^{13}$ y 18 inciso primero ${ }^{14}$ de la Ley 19.880). Por lo tanto, la declaración administrativa de terminación anticipada del contrato, en su carácter de resolución final o acto terminal ( $41^{15}$ de la Ley 19.880), también debe ser fundada. Y, adicionalmente, como la terminación anticipada de un contrato de concesión implica una privación de derechos para el concesionario, el acto administrativo que la declara debe estar motivado en virtud de lo dispuesto por el artículo 11 de la Ley 19.880: "Los hechos $y$ fundamentos de derecho deberán siempre expresarse en aquellos actos que afectaren los derechos de los particulares, sea que los... priven de ellos...".

b) El bien común o interés público como causa necesaria y general para fundar el acto que declara la terminación anticipada del contrato de concesión. Como se ha visto, la terminación anticipada de una concesión administrativa puede producirse "en cualquier momento, cuando sobrevenga un menoscabo o detrimento grave al uso común o cuando concurran otras razones de interés público" (artículo 36 inciso tercero de la Ley 18.695);

por la Ley $N^{\circ} 19.886$, en adelante, también, la "Ley de Compras". Y, asimismo, ya se ha observado por la doctrina: Lara, José Luis - García-Huidobro, Luis Eugenio, Sobre el régimen concesional chileno: ¿podemos hablar de un modelo de concesión?, en Soto-Kloss, (editor) Administración y Derecho. Homenaje a los 125 años de la Facultad de Derecho de la Pontificia Universidad Católica de Chile, (Thomson-Reuters La Ley, Santiago, 2014), pp. 102 y 103), que esto es así no sólo por las disposiciones propias de la contratación administrativa, sino que, merced al marco general ofrecido por la Ley 19.880, de Bases de los procedimientos administrativos que rigen los actos de los órganos de la Administración del Estado, el acto de adjudicación (artículo 41 inciso cuarto de dicha Ley), y la licitación que lo antecede (artículo 18 inciso primero de la misma), componen un procedimiento administrativo cuyo acto administrativo terminal o resolución final debe contener sus fundamentos.

${ }^{12}$ Ley 18.695, artículo 65 letra j): “El alcalde requerirá el acuerdo del concejo para: [...] j) Otorgar concesiones municipales, renovarlas y ponerles término. En todo caso, las renovaciones sólo podrán acordarse dentro de los seis meses que precedan a su expiración, aun cuando se trate de concesiones reguladas en leyes especiales".

13 "Concepto de Acto administrativo... I ... se entenderá por acto administrativo las decisiones formales que emitan los órganos de la Administración del Estado en las cuales se contienen declaraciones de voluntad, realizadas en el ejercicio de una potestad pública".

14 "... una sucesión de actos trámite vinculados entre sí, emanados de la Administración y, en su caso, de particulares interesados, que tiene por finalidad producir un acto administrativo terminal".

${ }^{15}$ Artículo 41: "Contenido de la resolución final... [...] Las resoluciones contendrán la decisión, que será fundada". 
o, pueden “...terminarse anticipadamente por... exigirlo el interés público o la seguridad nacional' (artículo 13, letra d), de la Ley 19.886). Estas no son simplemente causales legales particulares para la terminación de un contrato administrativo, sino que son emanaciones de un principio superior (por tanto, de aplicación permanente, general e invariable), que rige la contratación administrativa, por el cual la finalidad de estos negocios jurídicos debe preordenarse siempre al bien común.

En la jurisprudencia constitucional se ha dicho, siguiendo la doctrina ${ }^{16}$, que: “... los contratos regulados por la Ley $N^{\circ} 19.886$ se insertan dentro de los contratos administrativos que se caracterizan, entre otros factores, porque una parte es necesariamente una persona jurídica de Derecho Público (organismos constitucionalmente autónomos, servicios centralizados o descentralizados). Se trata, asimismo, de contratos regidos por normas de Derecho Público que consagran el principio de preeminencia de la Administración, la cual puede imponer su quebrantamiento legitimamente en virtud de su poder exorbitante de ius variandi cuando los intereses superiores que representa asi lo justifiquen. Ello se debe a que se trata de contratos en los que existe desigualdad de fines entre los contratantes pues el particular, usualmente, persigue un fin también particular mientras que la Administración procura una finalidad que obedece a fines de interés público" 17.

Tal como se acaba de señalar, la "preeminencia de la Administración" en un contrato se justifica absoluta y netamente por sus "intereses superiores", determinados por sus "fines de interés público". De allí que "La atribución que se entrega a la Administración de poner unilateralmente término anticipado al contrato requiere contar con la justificación de un interés público o general que le sirva de fundamento, como es el caso ejemplar de las concesiones municipales"18.

Por esto es que la jurisprudencia ha rechazado aquellas terminaciones anticipadas de concesiones administrativas que no han tenido por justificación un interés público objetivo y concreto sino, por ejemplo, la mera disconformidad de la comunidad o de la autoridad edilicia respecto de los términos del contrato de concesión ${ }^{19}$.

16 Barra, Nancy - Celis, Gabriel, Contratación administrativa bajo la Ley de Compras ( 3 a edición, Abeledo Perrot, Santiago, 2011), pp. 3 y 4.

17 Banco de Chile con Consejo de Defensa del Estado, Trib. Constitucional, requerimiento de inaplicabilidad por inconstitucionalidad del artículo 4 de la Ley 19.886, fecha 4.7.2013, Rol No 2133-2011 (Considerando OCTAVO), LegalPublishing Cita Online: CL/JUR/1544/2013.

${ }^{18}$ Moraga Klenner, Claudio, Contratación administrativa (Editorial Jurídica de Chile, Santiago, 2007), p. 244.

19 Ingeniería en Electrónica, Computación y Medicina S.A. con Alcalde de 
La justificación de la facultad de terminación anticipada del contrato descansa en el deber de propender al bien común que pesa sobre la Administración (artículo $1^{\circ}$ inciso cuarto de la Constitución Política y artículo 3 inciso primero de la Ley 18.575), al cual queda vinculada férreamente por el principio de juridicidad (artículo 7 de la Constitución Política y artículo 2 de la Ley 18.575). Este deber, por cierto, reconoce como límite interno que su consecución debe lograrse "con pleno respeto a los derechos y garantías que esta Constitución establece". Y por ello es que cualquiera sea el motivo por el que se termine anticipadamente la concesión, la pérdida de derechos del concesionario deberá en el caso concreto responder a una "causa de utilidad pública o de interés nacional, calificada por el legislador", para no atentar, inconstitucionalmente, contra la garantía del artículo 19 No 24 de la Constitución Política, que protege al concesionario en cuanto dueño de los derechos que para él emanan del contrato de concesión.

En virtud del principio constitucional de juridicidad, tal es la intensidad y magnitud tanto del deber de la promoción del bien común con pleno respeto a los derechos y garantías constitucionales de toda persona (artículo 1 inciso cuarto de la Carta Fundamental), como, asimismo, de la garantía constitucional del artículo 19 № 24, en cuanto protección de la propiedad sobre los derechos adquiridos por los particulares al interior de la contratación administrativa, que resulta inexcusable que la Administración, de manera permanente, general e invariable, justifique a través de la fundamentación del acto en qué sentido tal medida propende al bien común en ese caso concreto, aparte de la causa legal que necesariamente se invoque de manera adicional (ya sea del 36 o del 37 de la Ley 18.695; o bien, de cualquiera de las letras del artículo 13 de la Ley 19.886), para asegurar que no se está obrando, en virtud de potestades exorbitantes, con abuso de los derechos del particular.

Para ilustrar lo dicho, existe jurisprudencia favorable en materia de recurso de protección. La Ilustrísima Corte de Apelaciones de San Miguel conoció de un recurso de protección que versaba sobre la terminación anticipada de una concesión municipal de instalación y explotación de parquímetros. Las partes habían pactado en el contrato el carácter de obligación esencial a aquella contraída "Con el objeto de garantizar el fiel cumplimiento del contrato" consistente en la "entrega... de una boleta bancaria de garantía por la suma de cien Unidades de Fomento, documento que tendrá una vigencia de un año y que deberá ser renovado por periodos

la Ilustre Municipalidad de Puente Alto, Corte Apelaciones de San Miguel, recurso de protección, 28.6.2000, Rol No 65-2000 (Considerando, Octavo), LegalPublishing Cita Online: CL/JUR/474/2000. 
sucesivos hasta sesenta días después del término del contrato"20. La Municipalidad recurrida había terminado la concesión por no haberse entregado a tiempo, en efecto, la boleta bancaria que garantizaba las obligaciones del contrato $^{21}$. Pero la Corte, al observar que la recurrente tomó la boleta de garantía última, con anterioridad al vencimiento de la anterior ${ }^{22}$, aunque la hubiera ingresado con retraso de algunos días a oficinas de la recurrida, dictaminó que la recurrente "no ha incurrido en la grave falta a la Ley del Contrato, como le imputa la recurrida, puesto que la boleta de garantía se

${ }^{20}$ Ingeniería en Electrónica, Computación y Medicina S.A. con Alcalde de la Ilustre Municipalidad de Puente Alto, Sent. Corte Apelaciones de San Miguel recurso de protección, fecha 28.6.2000, Rol No 65-2000 (Considerando Tercero), LegalPublishing Cita Online: CL/JUR/474/2000.

${ }^{21}$ Sobre las características fundamentales de las boletas de garantía: GonZÁLEZ, Miguel, La boleta bancaria de garantía (Editorial Jurídica de Chile, Santiago, 1962), passim; WINTER, Rodrigo, Boleta de garantía. Serie de estudios financieros (Instituto de Estudios Bancarios Guillermo Subercaseaux, Santiago, 1995), passim; GONZÁlEZ, Joel, La boleta bancaria de garantía. Garantía a primer requerimiento (LexisNexis, Santiago, 2002), passim; Venegas, Loretto, Rc. Joel González, La boleta bancaria de garantía. Garantía a primer requerimiento, LexisNexis, Santiago, 2002, 214 pp., en Revista Chilena de Derecho 30 (2003) 1 pp. 207-208; Sото Kloss, Eduardo; MenDOZA, Ramiro, Presentación de una boleta de garantía errónea en un concurso público, en Revista Chilena de Derecho 20 (2003) pp. 179-199; AEdo, Cristián, Las garantías del acreedor frente al incumplimiento, en Revista Chilena de Derecho 35 (2008) 2, pp. 293-310; JEQUIER, Eduardo, Boleta de garantía bancaria e insolvencia. Su impacto en el principio de la par conditio creditorum, en Revista de Derecho, Universidad Católica del Norte 20 (2013) 2, pp. 175-179.

${ }^{22}$ Es del caso que la concesionaria entregó una primera boleta de garantía, tomada con fecha 25 de septiembre de 1998 y válida hasta el 27 de septiembre de 1999. Después, tomó una siguiente boleta de garantía, con fecha 22 de septiembre de 1999 y válida hasta el 29 de septiembre de 2000, la cual fue entregada a través de la oficina de partes de la municipalidad con fecha 7 de octubre de 1999 (la recurrente sostenía que días antes se había negado la recepción en la Dirección municipal correspondiente, pero no lo pudo probar). A consecuencia de los días que mediaron entre el vencimiento de la primera boleta, el día 27 de septiembre de 1999, y la efectiva entrega de la segunda, el día 7 de octubre de 1999 (a pesar de que la boleta misma se había tomado el 22 de septiembre de 1999), se declaró la caducidad de la concesión de parquímetros. Así, el 16 de marzo del año 2000 se notificó el Decreto alcaldicio exento, de fecha 2 de noviembre de 1999, en el cual se adoptó tal decisión siguiendo el acuerdo unánime del Concejo Municipal, adoptado en sesión ordinaria de fecha 21 de octubre de 1999, en orden a poner término al contrato de concesión por el incumplimiento de una obligación sustancial de la convención, como es la de no mantener vigente por todo el tiempo del contrato la garantía a que se encontraba obligado rendir, conforme lo disponen los artículos 32 y 33 de la Ley No 18.695, Orgánica constitucional de municipalidades, las cláusulas del contrato y las Bases Administrativas. 
tomó dentro de plazo, y en cuanto al atraso en su entrega, no significa en manera alguna dejar sin respaldo el contrato" 23 . Vale decir, la Corte tomó en consideración la relevancia sustancial de la concreta situación, en virtud de la cual, más allá de lo que dijera el contrato y de si había habido exacto cumplimiento de éste o no, la Municipalidad no había estado jamás en algún lapso sin garantías del cumplimiento de las obligaciones de la concesión: "en cuanto al atraso en su entrega, no significa en manera alguna dejar sin respaldo el contrato"; eso bastó para que la Corte declarara ilegal y arbitraria la terminación anticipada del contrato. Lo mismo podría decirse del criterio de la Contraloría General de la República, la cual, en el Dictamen No 1.450 de 2008, señaló respecto de una "la necesidad de exigir una caución... en orden a asegurar el cabal cumplimiento de la prestación comprometida...", que "no resulta procedente que, una vez comenzada la vigencia de un contrato determinado, éste se vea un instante siquiera desprovisto de tales cauciones" ${ }^{\prime 2}$. Vale decir, al igual que para nuestros Tribunales de Justicia, para la Contraloría General de la República el punto central de la cuestión de las garantías de cumplimiento del contrato no se reconduce a los específicos términos de las bases o del contrato, sino más bien al dato objetivo de si tal contrato ha estado, o no, asegurado en todo momento y a la manera en que se protegen los interés generales en juego, no los estrictos términos contractuales; ya que la terminación misma, no es una facultad meramente contractual de la Administración.

c) Las causas legales particulares para fundar el acto que declara la terminación anticipada del contrato de concesión. La legislación entrega diversas causas particulares por las que la Administración puede terminar anticipadamente un contrato. Así: el artículo 36 inciso tercero de la ley 18.695 ("cuando sobrevenga un menoscabo o detrimento grave al uso común o cuando concurran otras razones de interés público"); el artículo 37 inciso noveno ("La concesión sólo se extinguirá por las siguientes causales: 1.- Cumplimiento del plazo por el que se otorgó; 2.- Incumplimiento grave de las obligaciones impuestas al concesionario, y 3.- Mutuo acuerdo entre la municipalidad y el concesionario"); y, el artículo 13 de la Ley 19.886 (“a) La resciliación o mutuo acuerdo entre los contratantes; b) El incumplimiento grave de las obligaciones contraidas por el contratante; c) El estado de notoria

${ }^{23}$ Ingeniería en Electrónica, Computación y Medicina S.A. con Alcalde de la Ilustre Municipalidad de Puente Alto, Corte Apelaciones de San Miguel, recurso de protección, 28.6.2000, Rol No 65-2000 (Considerando Octavo), LegalPublishing Cita Online: CL/JUR/474/2000.

${ }^{24}$ Dictamen de Contraloría No 40.150, fecha 27.8.2008, ID Identificador: 040150N08, disponible en http://www.contraloria.cl/LegisJuri/DictamenesGeneralesMunicipales.nsf/FrameSetConsultaWebAnonima?OpenFrameset 
insolvencia del contratante, a menos que se mejoren las cauciones entregadas o las existentes sean suficientes para garantizar el cumplimiento del contrato; d) Por exigirlo el interés público o la seguridad nacional; e) Las demás que se establezcan en las respectivas bases de la licitación o en el contrato").

Tanto la jurisprudencia ${ }^{25}$ como la doctrina administrativista ${ }^{26}$ respaldan con firmeza que la declaración administrativa de terminación anticipada del contrato requiere fundarse en una causa legal. $\mathrm{Al}$ respecto, por ejemplo, se ha dicho por la jurisprudencia que para declararse la terminación en virtud del artículo 36 inciso tercero de la Ley 18.695, se "requiere de alguno de los dos presupuestos que allí se contemplan" 27 , y que no se puede declarar la terminación unilateral del contrato, tampoco, si "la atribución municipal de poner término unilateral a la concesión otorgada a la empresa recurrente no se encontraba prevista en las normas jurídicas acordadas" 28 . Y si resulta preceptivo invocar una causa legal, ello no sólo es porque dichas causas estén expresadas en la ley y porque de otro modo se vulneraría el principio de juridicidad (artículo 7 de la Constitución Política), sino también muy especialmente porque en el caso contrario se vulneraría al mismo tiempo el artículo 19 No 24 de la Carta Fundamental, en cuanto a que la "causa de utilidad pública o de interés nacional" que permita conculcar el derecho de propiedad sobre los derechos emanados de un contrato debe estar "calificada por el legislador".

Es importante destacar que ante una facultad tan excepcional como la terminación unilateral del contrato, la Administración no puede eludir la necesidad de que la causa que invoque sea legal por la vía de transformar obligaciones secundarias de la concesión en incumplimientos graves, a

${ }^{25}$ Revista de Derecho y Jurisprudencia (2a Parte, sección 5a) 83 (1986) p. 84; Gaceta Jurídica 81(1987) p. 23; Revista de Derecho y Jurisprudencia (2a Parte, sección 5a) 86(1989) p. 92.

${ }_{26}$ AróstiCA, Iván, Transferencia de funciones estatales al sector privado en tres contratos administrativos: concesión de servicio público, externalización y sociedad, en Revista de Derecho Público, Facultad de Derecho de la Universidad de Chile, 55-56 (1994) p. 144; VARGAS FrITZ, José Fernando, La concesión de obras públicas (Editorial La Ley, Santiago, 1997) p. 53; Lara, José Luis - García-Huidobro, Luis Eugenio, Sobre el régimen concesional chileno (cit. n. 10) p. 115.

27 Servicios de Estacionamientos Controlados S.A con I. Municipalidad De Melipilla, Corte Apelaciones de San Miguel, recurso de protección, 4.3.2011, Rol No 323-2010, (Considerando Decimotercero), LegalPublishing Cita Online: CL/ JUR/10647/2011.

${ }^{28}$ Servicios de Estacionamientos Controlados S.A con I. Municipalidad de Melipilla, Corte Apelaciones de San Miguel, recurso de protección, fecha 4.3.2011, Rol No 323-2010, (Considerando Decimotercero), LegalPublishing Cita Online: CL/ JUR/10647/2011. 
través de su incorporación extralegal, directa o indirecta, como cláusula especial del contrato de concesión de que se trate.

Al respecto puede dar una imagen engañosa el artículo 13 letra e) en relación con la letra b) de la Ley 19.886 , que establece como causas de la terminación anticipada: “e) Las demás que se establezcan en las respectivas bases de la licitación o en el contrato"; "b) El incumplimiento grave de las obligaciones contraidas por el contratante".

$\mathrm{Al}$ menos respecto de una concesión administrativa municipal, la Administración no puede homologar al incumplimiento grave dispuesto por la ley (artículo 13 letra b) de la Ley 19.886), uno que no lo sea, a través de las cláusulas de las bases o del contrato (artículo 13 letra e) de la Ley 19.886), pues carece de las facultades para ello incluso en circunstancias extraordinarias (artículo 7 de la Constitución). Si la Administración pudiera decidir por sí y ante sí, sin el respaldo de una ley expresa, que una obligación secundaria o de poca trascendencia o algún incumplimiento de poca entidad, de acuerdo a la finalidad práctica del contrato y a la esencia de su bilateralidad, en fin, un incumplimiento que objetivamente no sea grave, pudiere dar igualmente lugar a la terminación por la vía de fijarlo así en las bases de la licitación o en el contrato de concesión mismo, caerían por tierra las garantías constitucionales que exigen contar con normas de rango legal para ello (artículo $19 \mathrm{No}^{\circ} 21$ y 24 de la Carta Fundamental); además, por lo mismo quedaría como letra muerta los términos en que el constituyente le otorgó a la Administración el encargo de propender al bien común con pleno respeto a las garantías constitucionales de todos y de cada uno (artículo 1 inciso cuarto de la Constitución Política); asimismo, tampoco tendría efecto la reserva legal de la materia de las concesiones otorgada por el artículo 63 No 10 de la Constitución; y, por sobre todo, caería por su base el principio de juridicidad (artículo 7 de la Constitución), por el cual "en Derecho Público puede hacerse únicamente aquello a que autoriza expresamente la ley". Por tanto, no es (ni constitucionalmente podría ser) la propia norma del artículo 13 letra e) de la Ley 19.886 ("Las demás que se establezcan en las respectivas bases de la licitación o en el contrato"), una autorización para poner cualquier incumplimiento de las obligaciones de los contratos como “causa seudolegal” para que la Administración ejerza sus atribuciones exorbitantes de terminación.

Lo que en realidad quiere decir el artículo 13 letra e) de la Ley 19.886, en primer lugar, es que se podrá establecer casos de terminación anticipada en las bases de la licitación o en el contrato cuando así lo señalen expresamente las normas legales especiales que rijan una determinada concesión 
administrativa ${ }^{29}$. Así, entonces, de la multiplicidad de normas que rigen los distintos tipos de contratos administrativos, podría surgir una nueva causal particular de terminación anticipada por algún motivo que no coincida con los recogidos en el marco general ofrecido por el artículo 13 de la Ley 19.886. En segundo lugar, dicho artículo 13 letra e) no se refiere a los incumplimientos contractuales. Es decir, trata de hipótesis que no se relacionan con la letra b) ("El incumplimiento grave de las obligaciones contraidas por el contratante"). Esto es evidente, por cuanto, si bien en virtud de la letra e) ("Las demás que se establezcan en las respectivas bases de la licitación o en el contrato"), se podría producir la terminación, queda en pie la posibilidad de que el concesionario sea indemnizado. Y esto no podría ocurrir de ninguna manera en el caso del incumplimiento grave de la letra b) del mismo artículo, pues, el inciso final del artículo $36 \mathrm{de}$ la Ley 18.695 indica: "El concesionario tendrá derecho a indemnización en caso de término anticipado de la concesión, salvo que éste se haya producido por incumplimiento de las obligaciones de aquél'. Así es que la conclusión es obvia, las hipótesis de las letras b) y e) son distintas y, especialmente, la letra e) además de requerir que la ley especial autorice los contenidos particulares de las bases y el contrato de concesión administrativa de que se trate, no se refiere a incumplimientos de obligaciones como causal de terminación anticipada de la concesión sino a otras causas diversas. Por tanto, la administración no puede elevar a incumplimientos graves aquellos que objetivamente no lo sean.

Por otro lado, al ser la terminación anticipada y unilateral una emanación de las potestades públicas del ente administrativo, en el caso de la terminación por incumplimiento grave, no basta con sólo indicar o invocar la causal legal que se estime pertinente, ni la norma legal o contractual de la cual emane la obligación hipotéticamente incumplida. Si se atiende a los fundamentos y requisitos del Derecho público de los cuales emana este

${ }^{29}$ Los estatutos jurídicos son múltiples y dependen de diversos cuerpos normativos según la naturaleza de la concesión: concesión sobre el derecho de aprovechamiento de aguas; concesión de subsuelo de bienes nacionales de uso público; concesión de obra pública; concesión sanitaria; concesión de energía geotérmica; concesión de gas; concesión municipal; concesión portuaria; concesión de acuicultura; concesión de telecomunicaciones (general); concesión de servicio público telefónico; concesión de servicio de radiodifusión televisiva de libre recepción; concesión de radiodifusión sonora; concesión marítima; concesión aeronáutica; concesión de transporte público; concesión turística; concesión ferroviaria; licencia de operación de casino de juego; concesión de servicios eléctricos; concesión de uso de bienes nacionales; concesión de recintos e instalaciones deportivas; concesión de zona franca. Vid. Lara, José Luis - GarcíA-Huidobro, Luis Eugenio, Sobre el régimen concesional chileno (cit. N. 10) pp. 116 a 121. 
poder excepcional, se observa claramente que, además, se debe justificar la concreta, real y verdadera gravedad que deba atribuirse al incumplimiento y, asimismo, la manera en que el bien común está con ello comprometido. Pues, de otra forma, el órgano administrativo atendería sólo formalmente al deber de propender al bien común, atropellándose sustancialmente los derechos y garantías del concesionario, lo cual pugna con los artículos 1 inciso cuarto, 7 y 19 No 21 y No 24 de la Constitución Política ${ }^{30}$.

\section{Requisitos de derecho privado}

En cuanto a la terminación unilateral anticipada del contrato de concesión, ya se ha dicho en el apartado anterior que ello se debe realizar a través de un acto administrativo fundado del concedente, que se base en razones de bien común y que invoque además una causa legal. Por supuesto, esta posibilidad no está prevista en el Derecho privado chileno, de modo que la terminación anticipada del contrato es una institución propiamente de nuestro Derecho público. Pero, si bien esto es cierto e indudable, ello no se contradice con el hecho de que su tratamiento jurídico se complete con las normas del Derecho privado en aquello no regulado por el público (artículo 1 de la Ley 19.886). Esto, muy particularmente (aunque no sólo), cuando la causa invocada sea el incumplimiento grave de las obligaciones del contrato.

En efecto, en tal caso hay que recurrir al Derecho privado, a) tanto en cuanto es necesario deducir una acción de cumplimiento forzado del contrato y, eventualmente, además la indemnización de perjuicios. Por lo demás, b) la terminación anticipada del contrato administrativo por incumplimiento grave de las obligaciones por parte del concesionario es una institución análoga a la resolución del contrato bilateral por incumplimiento. En consecuencia, el primer requisito que se debe satisfacer es c) el "incumplimiento" de la obligación. Además, éste debe ser $d$ ) un "incumplimiento grave".

a) Acción de cumplimiento forzado más indemnización de perjuicios. La Ilustrísima Corte de Apelaciones de Iquique ${ }^{31}$ ha señalado, con acierto, que el incumplimiento contractual a partir del cual se emita la declaración de

30 Ingeniería en Electrónica, Computación y Medicina S.A. con Alcalde de la Ilustre Municipalidad de Puente Alto, Corte Apelaciones de San Miguel recurso de protección, fecha 28.6.2000, Rol No 65-2000 (Considerando Octavo), LegalPublishing Cita Online: CL/JUR/474/2000.

31 René Mancilla Campusano con Municipalidad de Iquique, Corte de Apelaciones de Iquique, reclamo de ilegalidad municipal, 20.2.2012, Rol No 569-2011 (Considerandos Séptimo y Octavo), LegalPublishing Cita Online: CL/ JUR/3856/2012. 
terminación anticipada de un contrato administrativo por incumplimiento grave es una cuestión que se deduce de la interpretación del contrato y sus efectos, lo que no es directamente un asunto relativo a las potestades públicas legales de la Municipalidad; y por ello es que no procede un recurso de ilegalidad contra la resolución alcaldicia que declara la terminación con fundamento en tal incumplimiento grave, sino que es una cuestión de lato conocimiento según el Derecho común. Asimismo, la Excelentísima Corte Suprema señaló, en el año 2013, que cuando se quiere dejar sin efecto una declaración administrativa de terminación anticipada de un contrato administrativo por incumplimiento, en la especie, una compraventa, el particular debía accionar para "instar por el cumplimiento forzado del contrato más la indemnización de perjuicios si lo estimaba pertinente" 32 .

Ahora, es menester recordar que, en materia de contratación administrativa, incluso si la terminación anticipada por incumplimiento de un contrato administrativo es declarada válida, ello no necesariamente frustra la pretensión indemnizatoria del particular ${ }^{33}$. De un lado, la indemnización se puede referir al valor de las prestaciones ya cumplidas por el concesionario, también a las prestaciones mutuas adeudadas entre las partes en razón de la terminación del contrato o, en general, a todo efecto civil consecuencia de la restitución de las cosas a su estado anterior y a la evitación del enriquecimiento sin causa ${ }^{34}$. Y, del otro, la privación de los derechos emanados del contrato de concesión realizada por la Adminis-

32 Aeroservicio S.A. con Dirección de Logística de Carabineros de Chile, Corte Suprema, recurso de casación en la forma y en el fondo, fecha 22.10.2013, Rol No 6329-2013 (Considerando Vigésimo), LegalPublishing Cita Online: CL/ JUR/2336/2013.

33 Finger Access S.A. con Ilustre Municipalidad de Antofagasta, Corte Suprema, casación en el fondo, 30.6.2008, Rol No 1370-2007 (Considerando Segundo), LegalPublishing Cita Online: CL/JUR/2785/2008.

${ }^{34}$ Corral, Hernán, Contratos y daños por incumplimiento (cit. n. 5) p. 237. Por otro lado, hay autores que señalan que las prestaciones mutuas sólo son indemnizatorias cuando dependen de una actuación de mala fe, pues es ésta la que constituye el hecho ilícito que está tras de toda responsabilidad extracontractual. Olvidan ellos que la indemnidad mira al daño no a la conducta que la provocó, como señalaba Alessandri, Arturo, De la responsabilidad extracontractual en el derecho civil chileno (Editorial Jurídica de Chile, Santiago, 2005), p. 394. Y, asimismo, que una conducta culpable no es en sí tampoco de mala fe (en la doctrina comparada, el incumplimiento de buena fe es, precisamente, el culpable, mientras el doloso se considera de mala fe), con lo cual habría que decir que de los cuasidelitos no deriva responsabilidad extracontractual por haber sólo culpa, lo cual es absurdo. Como sea, al sostener que las prestaciones mutuas sólo son indemnizatorias en casos de mala fe, queda entonces la duda obvia de si dichos autores creen que aquellas en que hay buena fe corresponden acaso a la responsabilidad contractual. Vid., con la opinión criticada, 
tración también da al concesionario el derecho al pago de un justo precio en el caso de que tal privación esté fundada en razones de bien común, tal como establece el artículo 19 No 24 de la Constitución Política. Por lo tanto, siempre será procedente la pretensión indemnizatoria, sea que la terminación se declare válida o no.

b) Terminación administrativa anticipada y resolución por incumplimiento. Tratándose de la declaración de terminación anticipada por incumplimiento grave de las obligaciones del contrato administrativo, la jurisprudencia ${ }^{35}$ no ha dudado en que ella tiene su respaldo último en el Derecho común representado por la acción resolutoria contenida en el artículo 1489 del Código Civil: "En los contratos bilaterales va envuelta la condición resolutoria de no cumplirse por uno de los contratantes lo pactado. (Inciso 2o) Pero en tal caso podrá el otro contratante pedir a su arbitrio o la resolución de contrato o el cumplimiento del contrato, con indemnización de perjuicios".

La llamada condición resolutoria tácita no es en realidad una modalidad, sino que nuestra jurisprudencia y nuestra doctrina modernas la reconocen como un efecto del incumplimiento ${ }^{36}$. Ante todo hay que tener en cuenta, según ya se dijo, que esta resolución por incumplimiento es considerada una institución excepcional en el Derecho privado ${ }^{37}$, por cuanto involucra una

Barros, Enrique, Tratado de responsabilidad extracontractual (Editorial Jurídica de Chile, Santiago, 2007, pero, reimp. de 2006), p. 872.

35 Aeroservicio S.A. con Dirección de Logística de Carabineros de Chile, Corte Suprema, recurso de casación en la forma y en el fondo, 22.10.2013, Rol No 6329-2013 (Considerando Decimonoveno y Vigésimo), LegalPublishing Cita Online: CL/JUR/2336/2013.

${ }^{36}$ La Excelentísima Corte Suprema ya ha señalado que ella no corresponde a la modalidad denominada condición resolutoria ordinaria, sino que es un efecto que emana de un incumplimiento contractual, el cual constituye un hecho ilícito del deudor y que, en calidad de tal, da origen a las facultades que aparecen en el artículo 1489. Coexpan Chile S.A. con Banco Security, Corte Suprema, recurso de casación en la forma y en el fondo, fecha 15.5.2014, Rol No 720-2013 (Prevención abogado integrante, Señor Raúl Lecaros), LegalPublishing Cita Online: CL/ JUR/2572/2014. En este sentido, PeÑAILILlo, Daniel, Obligaciones. Teoría general y clasificaciones. La resolución por incumplimiento (Editorial Jurídica de Chile, Santiago, 2003), p. 393; FueYo, Fernando, Cumplimiento e incumplimiento de las obligaciones (Editorial Jurídica de Chile, Santiago, ${ }^{32} 2004$ ), p. 294; Corral, Hernán, Contratos y daños por incumplimiento (cit. n. 5), pp. 223 y 224; MejíAs, Claudia, El incumplimiento resolutorio en el Código Civil (cit. n. 5), pp. 43 a 53.

${ }^{37}$ Rodríguez, Pablo, Extinción no convencional de las obligaciones (cit. n. 5), p. 213; Mejías, Claudia, El incumplimiento resolutorio en el Código Civil (cit. n. 5), p. 43; De la Maza, Íñigo, Contratos especiales (cit. n. 5) p. 249; Corral, Hernán, Contratos y daños por incumplimiento (cit. n. 5), p. 224. 
sanción o castigo para la parte incumplidora e implica una atenuación del principio de la fuerza vinculante del contrato (artículo 1.545 del Código Civil). Así, lo normal en el Derecho es que "los contratos se celebran para ser cumplidos" 38 y que, como señaló en su día Alessandri"39, "si el deudor no viola su compromiso, no tiene por qué indemnizar los perjuicios, ni por qué sufrir ninguna clase de castigos". Es, por tanto, por este carácter excepcional de la resolución por incumplimiento que para su ejercicio se exige que tal incumplimiento haya sido grave $\mathrm{e}^{40}$; lo cual, como dice Claro Solar ${ }^{41}$, es "una materia regida más bien por la equidad que por el rigor del derecho". Bajo estas premisas, la Excelentísima Corte Suprema ha señalado claramente, el año 2014, los requisitos generales para que opere la resolución por incumplimiento: "Que la facultad contemplada en el artículo 1489 del Código Civil, en orden a solicitar la resolución o el cumplimiento del contrato aparece como una forma de proteger al acreedor diligente y una sanción al deudor que ha faltado a su compromiso. Para que opere es necesario: a) que se trate de un contrato bilateral; b) que haya incumplimiento imputable de una obligación; c) que quien la pide haya cumplido o esté llano a cumplir su propia obligación y d) que sea declarada por sentencia judicial. En cuanto al incumplimiento de la obligación, éste puede ser total o parcial y se verifica ya sea porque no se ha cumplido integramente una obligación o porque siendo ellas varias, se han cumplido algunas y otras no. Empero, debe tratarse de incumplimiento de obligaciones que no revistan caracteres accesorios o secundarios, por cuanto no puede resolverse un contrato cuando se han cumplido las principales obligaciones en él contenidas, desde que ello no corresponde a la esencia de la institución derivada de la infracción de obligaciones recíprocas que constituyen la bilateralidad el contrato. En referencia a la imputabilidad del incumplimiento, debe ser voluntario e imputable, es decir, con dolo o culpa del deudor, no siendo procedente la resolución si ha mediado caso fortuito o fuerza mayor, por cuanto, en tal caso, se habrá extinguido la obligación por otro modo de poner término a la misma, como es la imposibilidad en el cum-

${ }^{38}$ Vío VÁSQUEZ, Efraín, Las obligaciones condicionales. Doctrina - Jurisprudencia - Legislación Comparada. Obra premiada por la Universidad de Concepción (Escuela Tipográfica Salesiana, Concepción, 1945), p. 287.

39 Alessandri, Arturo, Derecho civil. Teoría de las obligaciones (Editorial Jurídica Ediar-ConoSur Ltda., Santiago, 1988), p. 79.

${ }^{40}$ VIDAL, Álvaro, Cumplimiento e Incumplimiento Contractual en el Código Civil. Una perspectiva más realista, en Revista Chilena de Derecho 34 (2007) 1, pp. 41-59; VIDAL, Álvaro, La noción de incumplimiento esencial en el "Código Civil", en Revista de Derecho de la Pontificia Universidad Católica de Valparaíso 32(2009) pp. 237 a 240 .

${ }^{41}$ Claro Solar, Luis, Explicaciones de derecho civil chileno y comparado. De las obligaciones I (Imprenta Nascimento, Santiago, 1936) X, p. 191. 
plimiento. Seguidamente, se exige que el acreedor haya cumplido su propia obligación o esté llano a cumplirla y, pese a que tal presupuesto no se encuentra expresamente dispuesto en el precepto aludido, se desprende de las disposiciones que rigen el incumplimiento" 42.

Corresponde ahora detenerse en algunos aspectos puntuales, de relevancia, respecto de los requisitos de la resolución por incumplimiento contractual.

c) El incumplimiento. Para que opere la resolución del contrato por incumplimiento contractual, al igual que cuando la causal invocada por la Administración para la terminación anticipada sea el incumplimiento grave de las obligaciones del contrato por parte del concesionario, el primer requisito que se debe satisfacer es la existencia de tal incumplimiento.

Por supuesto, no hay lugar al incumplimiento si la obligación que se supone incumplida ya había sido pagada (artículos 1567 No 1 y 1568 del Código Civil $)^{43}$. Tampoco si había operado, y se alega, la prescripción extintiva de la acción del acreedor (artículo 1567 № 10); o porque se ha extinguido previamente la obligación por un acuerdo con el acreedor ${ }^{44}$, como en la novación, la transacción o la remisión (artículo 1567 Nos 2, 3 y 4 del Código Civil); o, sin haber extinción, si ha habido una renovación del plazo suspensivo del cual dependía la exigibilidad de la obligación, a través de un nuevo pacto ${ }^{45}$. En tales situaciones no podría haber resolución del contrato y, en cuanto a la terminación administrativa, el ente administrativo debería "resignar el ejercicio de su potestad unilateral de poner término a la concesión por incumplimiento grave de las obligaciones del concesionario"46.

Por otro lado, tampoco se puede pedir la resolución por aquella parte que no haya cumplido su propia obligación o no esté llana a cumplirla; caso en el cual su acción resolutoria será enervada en virtud de la exceptio non adimpleti contractus (excepción de contrato no cumplido), del artículo 1552 del Código Civil: "En los contratos bilaterales ninguno de los contratantes está

${ }^{42}$ Inversiones Clarkson y Compañía Limitada con Humberto Guillermo Donoso CaAmaño, Corte Suprema, casación en el fondo, fecha: 29.5.2014, Rol No 2073-2013 (Considerando 5o), LegalPublishing Cita Online: CL/JUR/2748/2014.

${ }^{43}$ Corral, Hernán, Contratos y daños por incumplimiento (cit. n. 5), p. 228 a 230.

${ }^{44}$ Aвeliuk, René, Las obligaciones (Editorial Jurídica de Chile, Santiago, ${ }^{52010),}$ 1, p. 654 .

${ }^{45}$ Fueyo, Fernando, Cumplimiento e incumplimiento (cit. n. 35), p. 165.

${ }^{46}$ En el caso había una transacción previa entre las partes. EMPRESA E.C.M. INgeniería S.A con Municipalidad Coquimbo, Corte Suprema, apelación recurso de protección, 2.1.2002, Rol No 4919-2001 (Considerando Tercero), LegalPublishing Cita Online: CL/JUR/167/2002; 19302. 
en mora dejando de cumplir lo pactado, mientras el otro no lo cumple por su parte, o no se allana a cumplirlo en la forma y tiempo debidos".

Es menester recordar que la Corte Suprema ${ }^{47}$ y la doctrina ${ }^{48}$ reconocen ampliamente la correlación entre la llamada condición resolutoria tácita ${ }^{49}$ y la excepción de contrato no cumplido ${ }^{50}$, tanto respecto de la necesidad de que exista un incumplimiento como de que dicho incumplimiento sea grave. Respecto del incumplimiento, este año 2014, la Excelentísima Corte Suprema ha discernido entre: “...la hipótesis [de la exceptio non rite adimpleti contractus] en que la demandada ha cumplido en forma imperfecta con su deber contractual, ya porque lo ha hecho en parte o de manera defectuosa, ya porque lo ha hecho en forma tardia... Asi, en la primera [la exceptio non adimpleti contractus] existe incumplimiento -puro o de gran envergadura o entidad-, en tanto que en la segunda el cumplimiento contractual existe pero no es cabal, debido nilu oportuno... '... Como la excepción de incumplimiento se apoya en la falta de cumplimiento, asi la excepción rite non adimpleti contractus se apoya en el cumplimiento inexacto (es decir, par-

47 Quintero Ponce, Jaime con Sociedad de Turismo Concepción S. A., Corte Suprema, recursos de casación en la forma y en el fondo, fecha 26.9.2012, Rol No 1127-2012 (Considerando Décimo, 12a), LegalPublishing Cita online: CL/ JUR/2116/2012; 62791; Urzúa Millán, Santiago Ramón con Fisco de Chile, Corte de Apelaciones de Coyhaique, recurso de casación y apelación en subsidio, 4.12.2007, Rol No 113-2007 (Considerando Decimosegundo), LegalPublishing Cita Online: CL/JUR/2823/2007.

48 Pizarro WiLSON, Carlos, La excepción por incumplimiento contractual en el Derecho Civil chileno, en Estudios de Derecho Civil, I. Jornadas Nacionales de Derecho Civil. Valdivia, 2005” (LexisNexis, Santiago, 2005), pp. 317-342; VIDAL, Álvaro, La noción de incumplimiento esencial (cit. n 39) pp. 237 a 255; CAprile, Bruno, Algunos problemas ofrecidos por la excepción de contrato no cumplido y, en especial, el de su invocación para atajar la acción resolutoria en el caso de incumplimiento recíproco de los contratantes, en Revista de Derecho de la Pontificia Universidad Católica de Valparaíso 39(2012), pp. 58 y 59; MEjíAs, Claudia, La excepción de contrato no cumplido y su consagración en el Código Civil chileno, en Revista Chilena de Derecho 40 (2013) 2, pp. 389-412.

49 Coexpan Chile S.A. con Banco Security, Corte Suprema, recurso de casación en la forma y en el fondo, 15.5.2014, Rol No 720-2013 (Prevención abogado integrante, Señor Raúl Lecaros), LegalPublishing Cita Online: CL/JUR/2572/2014. Vid., por todos, en este sentido, PeŃailillo, Daniel, Obligaciones (cit. n. 35), p. 393; Fueyo, Fernando, Cumplimiento e incumplimiento (cit. n. 35), p. 294; Corral, Hernán, Contratos y daños por incumplimiento (cit. n. 5), pp. 223 y 224.

${ }^{50}$ Contra, aunque sin éxito en el resto de la doctrina ni en la jurisprudencia respecto de este punto, AlCALDE, Enrique, Acción resolutoria y excepción de contrato no cumplido, en Revista Actualidad Jurídica, Universidad del Desarrollo 8 (2003) pp. 69-83; AlCALDE, Enrique, Incumplimiento recíproco, resolución y cumplimiento de contrato bilateral, en Revista Chilena de Derecho 31 (2004) 3, pp. 565-573. 
cial o no del todo conforme con los requisitos de tiempo, lugar y modalidades del incumplimiento)' (Doctrina General del Contrato; T. II; Eds. Jurídicas Europa América. Buenos Aires; pág. 438)"s1.

Aquí se pone de relieve, en consecuencia, que hay diversas maneras en las que se puede verificar el incumplimiento. No se puede perder de vista que el inciso primero del artículo 1556 del Código Civil señala que puede "no haberse cumplido la obligación, o... haberse cumplido imperfectamente, o... haberse retardado el cumplimiento". Es decir, el propio Código no reduce la cuestión del incumplimiento a la lisa y llana ausencia de éste, sino que reconoce hipótesis diversas y matizadas, incluyendo el cumplimiento imperfecto y el cumplimiento tardío. Lo que se debe poner de relieve, es que no todos ellos dan lugar a la excepción de contrato no cumplido o a la resolución por incumplimiento contractual (que es lo que ahora interesa).

d) El incumplimiento grave. Respecto de la trascendencia o suficiente entidad del incumplimiento, para nuestra jurisprudencia ${ }^{52}$ y doctrina ${ }^{53}$ la aplicación del artículo 1552 del Código Civil (asimilable al problema de la resolución, como ya se explicó), abarca todos los incumplimientos de carácter importante, es decir, todos aquellos por cuya entidad se

51 Lorca Villagrán Nelson Andrés con Sociedad Comercial HorizonTE LimitadA, Corte Suprema, recurso de casación en la forma, 18.3.2014, Rol No 951-2013 (Considerando 12 ), LegalPublishing Cita online: CL/JUR/454/2014; 68105. En los mismos términos, Industrias Lahsen Limitada con Constructora Puerto Iquique S.A., Corte Suprema, casación en el fondo, 27.8.2013, Rol: 76352012 (Considerando Undécimo), LegalPublishing Cita online: CL/JUR/1898/2013; 66035: "Que sin perjuicio de lo dicho, existe un matiz que, a la luz de los hechos de la litis, amerita ser puesto de relieve... la hipótesis en que el acreedor demandante ha cumplido en forma imperfecta con su deber contractual, ya porque lo ha hecho en parte o de manera defectuosa, ya porque lo ha hecho en forma tardía, que es precisamente lo ocurrido en la especie, según da cuenta la Corte de Apelaciones de Iquique en su fallo. Así, en la primera existe incumplimiento -puro o de gran envergadura o entidad-, en tanto que en la segunda el cumplimiento contractual existe pero no es cabal, debido ni/u oportuno... Al respecto, se ha escrito que... la excepción de incumplimiento se apoya en la falta de cumplimiento... la excepción rite non adimpleti contractus se apoya en el cumplimiento inexacto (es decir, parcial o no del todo conforme con los requisitos de tiempo, lugar y modalidades del incumplimiento) (Doctrina General del Contrato; T. II; Eds. Jurídicas Europa América. Buenos Aires; pág. 438)".

52 Cfr. Lorca Villagrán Nelson Andrés con Sociedad Comercial Horizonte LimitadA, Corte Suprema, recurso de casación en la forma, 18.3.2014, Rol No 9512013 (Considerando 11 ${ }^{\circ}$ ), LegalPublishing Cita online: CL/JUR/454/2014; 68105; Industrias Lahsen Limitada con Constructora Puerto Iquique S.A., Sent. Corte Suprema casación en el fondo, fecha 27.8.2013, Rol: 7635-2012 ("Considerando, Undécimo”), LegalPublishing Cita online: CL/JUR/1898/2013; 66035.

53 Vid. Pizarro Wilson, Carlos, La excepción por incumplimiento contractual (cit. n. 47), pp. 317-342. 
infrinja el deber del comportamiento de buena fe. Esto está en la línea de los fundamentos para justificar la institución misma de la resolución por incumplimiento; dentro de los cuales, el que tiene mayor acogida y resulta más claro para explicar por qué la resolución debe fundarse en un incumplimiento grave, es el de la interdependencia en las prestaciones y su debido equilibrio, o, lo mismo, la equidad de las prestaciones recípro$\mathrm{cas}^{54}$-medido el mérito de la finalidad del contrato desde el punto de vista económico y aun moral, pero, en todo caso, concreto y práctico- $-^{55}$. De hecho, el fundamento de la equidad como eje de la resolución del contrato por incumplimiento está consagrado en nuestra jurisprudencia en dos sentencias clásicas en la materia. La primera sentencia es del año 1920: “...la falta de cumplimiento de las demás obligaciones accesorias... no es bastante para determinar la resolución del contrato, por más absolutos en que aparezcan los términos en que está concebida la disposición del artículo 1489 del Código Civil, dado que tratándose de una materia tradicional como ésta (la resolución), que es regida por la equidad antes que por el derecho, o mejor dicho, en la cual las disposiciones legales que la rigen aparecen inspiradas únicamente en principios de equidad natural, debe decidirse la resolución o negarse lugar a ella, según las circunstancias de la causa, circunstancias que, en este caso, inducen a negar lugar a la acción resolutoria en razón de que habida consideración a la poca o ninguna influencia de estas obligaciones en los fines prácticos del comprador..." 56 .

La segunda, por su parte, es de 1931: "Que el artículo 1489 del Código Civil envuelve una regla que rige exclusivamente la situación que se produce en los contratos bilaterales cuando una de las partes ha cumplido o está llana a cumplir el contrato y la otra se niega a hacerlo, ya que así expresa de un modo inequivoco el inciso primero al disponer que en los contratos bilaterales va envuelta la condición resolutoria de no cumplirse por uno de los contratantes lo pactado y el inciso segundo, corrobora este sentido otorgando al otro contratante el derecho alternativo de pedir la resolución o el cumplimiento del contrato con indemnización de perjuicios, sanción ésta que sería absolutamente antijurídica y, por lo mismo, fuera de razón, si se estimare que la ley acuerda en favor del otro contratante que tampoco hubiera cumplido con sus obliga-

${ }^{44}$ Dávila, Óscar; Cañas, Rafael, Esplicaciones de código civil (clase de don Leopoldo Urrutia). De las obligaciones en general y de los contratos (Imprenta Cervantes, Santiago, 1907), p. 60; Claro SOLAR, Luis, Explicaciones de derecho civil chileno y comparado. $X$ (cit. n. 40), p. 191; Vío VÁsQUEZ, Efraín, Las obligaciones condicionales. (cit. n. 37), pp. 245 a 247; PeÑaILILlo, Daniel, Obligaciones (cit. n. 35), pp. 395 a 398.

55 FuEYo, Fernando: Cumplimiento e incumplimiento (cit. n. 35), p. 313.

${ }^{56}$ Grace, W. R. con Bustos Raúl, Corte de Apelaciones de Talca, 12.11.1920, en Revista Gaceta de los Tribunales, segundo semestre, 142 pp. 610-617. 
ciones. Confirman esta interpretación los fundamentos racionales de equidad y justicia que inspiran esa disposición, que no son otros que subentender o presumir que en los contratos bilaterales cada una de las partes consiente en obligarse a condición de que la otra se obligue a su vez para con ella, o sea, la reciprocidad de las obligaciones acarrea necesariamente la de las prestaciones" ${ }^{57}$.

Por cierto, como corolario de la equidad en que se funda la aplicación del artículo 1489, ya la sentencia de 1920 señala que no se debe atender a los incumplimientos de poca relevancia para dar lugar a la resolución ${ }^{58}$. Con ello también está conteste la doctrina actual ${ }^{59}$; pues, de lo contrario, podría "dejarse sin efecto un contrato por minucias, y en seguida, porque no corresponde a la esencia de la institución, derivada de la infracción de las obligaciones reciprocas que constituyen la bilateralidad del contrato: el precio y la cosa en la venta, la renta y el goce en el arrendamiento, etc." ${ }^{60}$. Y se añade, por lo mismo, que "no estamos de acuerdo en que el incumplimiento de algunas obligaciones del mismo contrato, de carácter totalmente accesorio y secundario, no obstante haberse cumplido las principales, pueda dar lugar a la resolución" ${ }^{61}$. Por su parte, estas consideraciones también son las que dominan en la jurisprudencia, hoy ${ }^{62}$. Así, la Excelentísima Corte Suprema

57 Corte Suprema (Considerandos $15^{\circ}$ y 16 ${ }^{\circ}$ ), en Revista de Derecho y Jurisprudencia y Gaceta de los Tribunales 28 (1931), sec. 2a , p. 689.

58 PeŃallillo, Daniel, Obligaciones (cit. n. 35), pp. 406 a 409.

59 Vid. Claro Solar, Luis: Explicaciones de derecho civil chileno y comparado. $X$ (cit. n. 35), p. 191; PeÑaIlillo, Daniel, Obligaciones (cit. n. 35), p. 406 a 409; AlCALDE, Enrique, Acción resolutoria y excepción de contrato no cumplido (cit. n. 49), pp. 69-83; AlCALDE, Enrique, Distinción entre obligaciones principales y secundarias (cit. n. 49) pp. 387-395; AlCALDE, Enrique: Incumplimiento recíproco, resolución y cumplimiento de contrato bilateral', en Revista Chilena de Derecho 31 (2004) 3, pp. 565573; FueYo, Fernando, Cumplimiento e incumplimiento (cit. n. 35), p. 313; VIDAL, Álvaro, Cumplimiento e Incumplimiento Contractual (cit. n. 39) pp. 41-59; Barros, Enrique, Finalidad y alcance de las acciones y los remedios contractuales, en PiZARro, Carlos (editor), Estudios de Derecho Civil IV. Jornadas Nacionales de Derecho Civil (LegalPublishing, Santiago, 2008), pp. 422 y 423; VIDAL, Álvaro: La noción de incumplimiento esencial (cit. n. 39) pp. 237 a 240; ABELIUK, René, Las obligaciones, (cit. n. 43) 1, p. 517; CoRRAL, Hernán, Contratos y daños por incumplimiento (cit. n. 5), p. 226; VIDAL, Álvaro: El incumplimiento de obligaciones con objeto fungible y los remedios del acreedor afectado. Una relectura de las disposiciones del Código Civil sobre incumplimiento, en PizArro, Carlos -VIDAL, Álvaro Incumplimiento Contractual, Resolución e Indemnización de Daños (Editorial Universidad del Rosario, Bogotá, 2010), p. 186 n. 113; MejÍAs, Claudia, El incumplimiento resolutorio en el Código Civil (cit. n. 5), p. 43; De la Maza, Ínigo, Contratos especiales (cit. n. 5) p. 249.

${ }^{60}$ AbeliuK, René, Las obligaciones (cit. n. 43) 1, p. 517.

${ }^{61}$ AbeliuK, René, Las obligaciones (cit. n. 43), 1, p. 517.

${ }^{62}$ Inversiones Clarkson y Compañía Limitada con Humberto Guillermo Donoso CaAmaño, Corte Suprema, casación en el fondo, 29.5.2014, Rol No 2073- 
ha reafirmado que no basta cualquier incumplimiento, pues: “...no procede pedir la resolución del contrato... por incumplimiento de obligaciones accesorias, no condicionantes o de escasa entidad, si se ha cumplido con las obligaciones principales. Para descartar un aparente mandato absoluto del artículo 1489 del Código Civil, es pertinente recordar que el inciso final del artículo 1852 del citado código dispone que, si la evicción no recae sobre toda la cosa vendida y la parte evicta es tal que sea de presumir que no se habría comprado la cosa sin ella, habrá derecho a pedir la resolución de la venta" ${ }^{3}$.

Finalmente, un reflejo de lo mismo es que en materia civil la resolución por incumplimiento contractual tampoco puede ser "utilizada para deshacerse de contratos molestos o meramente inconvenientes" "64; lo cual también ha pasado a la jurisprudencia de Derecho administrativo, precisamente respecto de la terminación anticipada de las concesiones administrativas, pues se ha dicho que ésta no puede fundarse en la mera disconformidad de la comunidad o de la autoridad edilicia respecto de los términos del contrato de concesión ${ }^{65}$,

Tomando lo señalado hasta aquí, la resolución del contrato tiene lugar respecto de obligaciones que "constituyen la bilateralidad del contrato"66 y cuyo incumplimiento rompe el "equilibrio" o "equidad" contractual ${ }^{67}$ (y, en este sentido, infringe el deber del comportamiento de buena fe $)^{68}$,

2013 (Considerando 5º), LegalPublishing Cita Online: CL/JUR/2748/2014; LorCA Villagrán Nelson Andrés con Sociedad Comercial Horizonte Limitada, Corte Suprema, recurso de casación en la forma, 18.3.2014, Rol No 951-2013 (Considerando, $1^{\circ}$ ), LegalPublishing Cita online: CL/JUR/454/2014; 68105; INDUSTRIAS Lahsen Limitada con Constructora Puerto Iquique S.A., Corte Suprema, casación en el fondo, 27.8.2013, Rol: 7635-2012 (Considerando Undécimo), LegalPublishing Cita online: CL/JUR/1898/2013; 66035.

63 Quintero Ponce, Jaime con Sociedad de Turismo Concepción S. A., Corte Suprema, recursos de casación en la forma y en el fondo, 26.9.2012, Rol No 1127-2012 (Considerando Décimo, 13a), LegalPublishing Cita online: CL/ JUR/2116/2012; 62791.

${ }^{64}$ Corral, Hernán, Contratos y daños por incumplimiento (cit. n. 5), p. 226.

65 Ingeniería en Electrónica, Computación y Medicina S.A. con Alcalde de la Ilustre Municipalidad de Puente Alto, Corte Apelaciones de San Miguel, recurso de protección, fecha 28.6.2000, Rol No 65-2000 (Considerando Octavo), LegalPublishing Cita Online: CL/JUR/474/2000.

${ }^{66}$ Abeliuk, René, Las obligaciones (cit. n. 43) 1, p. 517.

${ }^{67}$ Peñallillo, Daniel, Obligaciones (cit. n. 35), pp. 395 a 398.

68 Cfr. Lorca Villagrán Nelson Andrés con Sociedad Comercial Horizonte LimitadA, Corte Suprema, recurso de casación en la forma, 18.3.2014, Rol No 9512013, (Considerando 110), LegalPublishing Cita online: CL/JUR/454/2014; 68105; Industrias Lahsen Limitada con Constructora Puerto Iquique S.A., Corte Suprema, casación en el fondo, 27.8.2013, Rol: 7635-2012 (Considerando Undécimo), 
al incidir de manera importante en los "fines prácticos" ${ }^{69}$ perseguidos por las partes. Por contraste, no permiten que la resolución del contrato tenga lugar, los incumplimientos de poca relevancia ${ }^{70}$ y referidos a "minucias" ${ }^{1}$, como es el caso de obligaciones "secundarias"72, "accesorias"73, "no condicionantes o de escasa entidad" "7 ni tampoco puede ser un mecanismo "para deshacerse de contratos molestos o meramente inconvenientes"75. En suma, para una terminación unilateral anticipada "plus est in re quam in existimatione".

\section{BibLIOGRAFÍA}

Abeliuk, René, Las obligaciones (5 $5^{\mathrm{a}}$ edición, Editorial Jurídica de Chile, Santiago, 2010) I.

AEdo, Cristián, Las garantías del acreedor frente al incumplimiento, en Revista Chilena de Derecho 35 (2008) 2, pp. 293-310.

AlCALDE, Enrique, Acción resolutoria y excepción de contrato no cumplido, en Revista Actualidad Jurídica, Universidad del Desarrollo 8 (2003) pp. 69-83.

AlCALDE, Enrique, Incumplimiento recíproco, resolución y cumplimiento de contrato bilateral, en Revista Chilena de Derecho 31 (2004) 3, pp. 565-573.

Alessandri, Arturo, Derecho civil. Teoría de las obligaciones (Editorial Jurídica EdiarConoSur Ltda., Santiago, 1988).

AlESSANDRI, Arturo, De la responsabilidad extracontractual en el derecho civil chileno (Editorial Jurídica de Chile, Santiago, 2005).

ARÓSTICA, Iván, Transferencia de funciones estatales al sector privado en tres contratos administrativos: concesión de servicio público, externalización y sociedad, en Revista de Derecho Público, Facultad de Derecho de la Universidad de Chile, 55-56 (1994) pp. 143-160.

LegalPublishing Cita online: CL/JUR/1898/2013; 66035. Vid. Pizarro Wilson, Carlos: La excepción por incumplimiento contractual (cit. n. 47), pp. 317-342.

69 Grace, W. R. con Bustos Raúl, Corte de Apelaciones de Talca, fecha 12.11.1920, Revista Gaceta de los Tribunales, segundo semestre, 142 pp. 610-617. Vid. Fueyo, Fernando, Cumplimiento e incumplimiento de las obligaciones (cit. n. 35), p. 313.

70 Peñallillo, Daniel, Obligaciones (cit. n. 35), pp. 406 a 409.

${ }^{71}$ Abeliuk, René, Las obligaciones, (cit. n. 43) 1, p. 517.

72 Abeliuk, René, Las obligaciones (cit. n. 43) 1, p. 517.

73 Grace, W. R. con Bustos Raúl, Corte de Apelaciones de Talca, 12.11.1920, Revista Gaceta de los Tribunales, segundo semestre, 142 pp. 610-617. Vid. VIDAL, Á., El incumplimiento de obligaciones con objeto fungible y los remedios del acreedor afectado (cit. n. 58) p. 186 n. 113.

74 Quintero Ponce, Jaime con Sociedad de Turismo Concepción S. A., Corte Suprema, recursos de casación en la forma y en el fondo, 26.9.2012, Rol No 1127-2012 (Considerando Décimo, 13a), LegalPublishing Cita online: CL/ JUR/2116/2012; 62791.

${ }^{75}$ Corral, Hernán, Contratos y daños por incumplimiento (cit. n. 5), p. 226. 
Barra, Nancy; Celis, Gabriel, Contratación administrativa bajo la Ley de Compras (Abeledo Perrot, Santiago, ${ }^{3} 2011$ ).

Barros, Enrique, Finalidad y alcance de las acciones y los remedios contractuales, en PiZArro, Carlos (editor), Estudios de Derecho Civil IV. Jornadas Nacionales de Derecho Civil (LegalPublishing, Santiago, 2008), pp. 403-428.

Barros, Enrique, Tratado de responsabilidad extracontractual (Editorial Jurídica de Chile, Santiago, 2007, reimp. de edición de 2006).

Caprile, Bruno, Algunos problemas ofrecidos por la excepción de contrato no cumplido $y$, en especial, el de su invocación para atajar la acción resolutoria en el caso de incumplimiento recíproco de los contratantes, en Revista de Derecho de la Pontificia Universidad Católica de Valparaíso 39 (2012), pp. 58 y 59.

Carvajal, Patricio-Ignacio, La compraventa a un impúber sin autorización del tutor. Un estado de la cuestión en torno a D. 41,4,2,15, en REHJ. 33 (2011), pp. 145-171.

Claro Solar, Luis, Explicaciones de derecho civil chileno y comparado. De las obligaciones I (Imprenta Nascimento, Santiago, 1936).

Corral, Hernán, Contratos y daños por incumplimiento. Estudios sobre su régimen jurídico y la responsabilidad por incumplimiento (Abeledo Perrot - LegalPublishing, Santiago, 2010).

DÁvila, Óscar; Cañas, Rafael, Esplicaciones de Código civil (clase de don Leopoldo Urrutia). De las obligaciones en general y de los contratos (Imprenta Cervantes, Santiago, 1907).

De la Maza, Íñigo, Contratos especiales (Comentarios de jurisprudencia), en Revista Chilena de Derecho Privado 17 (2011) p. 249.

ElORRIAGA, Fabián, Las dificultades de los remedios por incumplimiento contractual en la experiencia chilena, en Mondaca, Alexis -Aedo, Cristián (editores), Nuevos Horizontes del Derecho Privado (Librotecnia, Santiago, 2013), pp. 385 a 419.

Fueyo, Fernando, Cumplimiento e incumplimiento de las obligaciones (3a edición, Editorial Jurídica de Chile, Santiago, 2004).

GonZÁleZ, Joel, La boleta bancaria de garantía. Garantía a primer requerimiento (LexisNexis, Santiago, 2002).

GonzÁlez, Miguel, La boleta bancaria de garantía (Editorial Jurídica de Chile, Santiago, 1962).

GuZMÁn Brito, Alejandro, La interpretación administrativa en el derecho chileno (Thomson Reuters La Ley, Santiago, 2014).

GuZMÁn BRITO, Alejandro, El origen y la expansion de la idea de principio del derecho (Thomson Reuters La Ley, Santiago, 2014).

JEQUIER, Eduardo, Boleta de garantía bancaria e insolvencia. Su impacto en el principio de la par conditio creditorum, en Revista de Derecho, Universidad Católica del Norte 20 (2013) 2 pp. 175-199.

LARA, José Luis; GARCÍA-HuIDOBRO, Luis Eugenio: Sobre el régimen concesional chileno: ¿podemos hablar de un modelo de concesión?, en Soto-KLoss, Eduardo (editor) Administración y Derecho. Homenaje a los 125 años de la Facultad de Derecho de la Pontificia Universidad Católica de Chile" (Thomson-Reuters La Ley, Santiago, 2014) pp. 89-165.

Mejías, Claudia, La excepción de contrato no cumplido y su consagración en el Código Civil chileno, en Revista Chilena de Derecho 40(2013) 2, pp. 389-412.

Mejías, Claudia, El incumplimiento resolutorio en el Código Civil (Abeledo Perrot, Santiago, 2011). 
Moraga Klenner, Claudio, Contratación administrativa (Editorial Jurídica de Chile, Santiago, 2007).

Peñailillo, Daniel, Obligaciones. Teoría general y clasificaciones. La resolución por incumplimiento (Editorial Jurídica de Chile, Santiago, 2003).

Pizarro Wilson, Carlos, La excepción por incumplimiento contractual en el Derecho Civil chileno, en Estudios de Derecho Civil, I. Jornadas Nacionales de Derecho Civil (LexisNexis, Santiago, 2005), pp. 317-342.

Pizarro, Carlos, ¿Puede el acreedor poner término unilateral al contrato?, en Revista Ius et Praxis 13 (2007) 1, pp. 11-28.

Rodríguez, Pablo, Extinción no convencional de las obligaciones (Editorial Jurídica de Chile, Santiago, 2008).

Soto Kloss, Eduardo - Mendoza, Ramiro, Presentación de una boleta de garantía errónea en un concurso público, en Revista Chilena de Derecho 20 (2003) pp. 179-199.

Vargas Fritz, José Fernando, La concesión de obras públicas (Editorial La Ley, Santiago, 1997).

Venegas, Loretto, Recensión a Joel González, La boleta bancaria de garantía . Garantía a primer requerimiento, LexisNexis, Santiago, 2002, 214 pp., en Revista Chilena de Derecho 30 (2003) 1 pp. 207-208.

VIDAL, Álvaro, Cumplimiento e Incumplimiento Contractual en el Código Civil. Una perspectiva más realista, en Revista Chilena de Derecho 34(2007)1 pp. 41-59.

VIDAL, Álvaro, La noción de incumplimiento esencial en el "Código Civil", en Revista de Derecho de la Pontificia Universidad Católica de Valparaiso 32 (2009) pp. 237 a 240.

VIDAL, Álvaro: El incumplimiento de obligaciones con objeto fungible y los remedios del acreedor afectado. Una relectura de las disposiciones del Código Civil sobre incumplimiento, en Pizarro, Carlos - Vidal, Álvaro, Incumplimiento Contractual, Resolución e Indemnización de Daños, (Editorial Universidad del Rosario, Bogotá, 2010).

Vío VÁsquez, Efraín, Las obligaciones condicionales. Doctrina - Jurisprudencia - Legislación Comparada. Obra premiada por la Universidad de Concepción (Escuela Tipográfica Salesiana, Concepción, 1945).

WINTER, Rodrigo, Boleta de garantía. Serie de estudios financieros (Instituto de Estudios Bancarios Guillermo Subercaseaux, Santiago, 1995). 
